\title{
Lingual Lipase and Its Role in the Digestion of Dietary Lipid
}

\author{
Margit Hamosh and Robert O. Scow \\ From the Section on Endocrinology, Laboratory of Nutrition and Endocrinology, \\ National Institute of Arthritis and Metabolic Diseases, \\ Bethesda, Maryland 20014
}

\begin{abstract}
A B S TRACT The serous glands of rat tongue were found to contain a potent lipolytic enzyme which hydrolyzed triglyceride to mostly diglyceride and free fatty acids (FFA) at $\mathrm{pH}$ 4.5-5.4. Homogenates of lingual serous glands from adult rats hydrolyzed $40-70 \mathrm{mmol}$ of triglyceride/g per $h$. The soft palate, anterior oral pharyngeal wall, and lateral oral pharyngeal glands also contained the activity, but at a much lower level. The lipolytic activity was also found in saliva collected through an esophageal cannula and in stomach contents of rats fed a fat-rich meal. The stomach contained very little activity, however, when saliva was excluded. Lipolytic activity was not found in the stomach wall or in the parotid, submandibular, and sublingual glands. The findings suggest that the lingual serous glands secrete a lipase which catalyzes in the stomach the conversion of triglyceride to partial glycerides and FFA. It is proposed that this reaction is the first step in the digestion of dietary lipid.
\end{abstract}

\section{INTRODUCTION}

Milk triglyceride is hydrolyzed to partial glycerides and FFA in the stomach of suckling rats $(1,2)$. Although gastric mucosa of adult rats readily hydrolyzes medium chain triglycerides $(3,4)$, it has very little effect on long chain triglycerides (3), the major constituent of milk lipid (2). Lipolytic activity has been found in the milk of several species (5-8), but the activity present in rat milk (9) is too low to account for the hydrolysis of milk triglyceride in the stomach of suckling rats. Regurgitation of pancreatic secretion might explain some of the lipolytic activity found in stomach $(3,10)$, but the absence of bile in the stomach content of the suckling rats (Unpublished observations of Hamosh, M. and R. O. Scow) suggests that regurgitation did not occur. The

This work was presented in part at the 1971 Annual Meeting of the Eastern Section of the American Federation for Clinical Research, Philadelphia, $\mathrm{Pa}$.

Received for publication 15 June 1972 and in revised form 1 September 1972. saliva of calves contains a lipolytic activity, called "pregastric esterase," which hydrolyzes triglyceride to FFA in the stomach (11). Glandular tissue from the back region of the tongue, the glossoepiglottic area of the pharynx, and the pharyngeal end of the esophagus also contained the activity (12). Therefore, the secretory tissues of the mouth of suckling and adult rats were examined for lipolytic activity. This paper describes a potent lipase found in the tongue and its possible role in the digestion of triglyceride.

\section{METHODS}

Animals. Adult female (Charles River, Charles River Breeding Labs., Inc., Wilmington, Mass.) and 3 to 6-day old suckling (Sprague-Dawley) rats were used in these experiments. The adult rats were fed ad lib. Purina Laboratory Chow (Ralston Purina Co., St. Louis, Mo.).

Saliva was collected and excluded from the stomach in adult rats fasted overnight by inserting a cannula of AWG10 vinyl tubing (Temflex, 3M Company, St. Paul, Minn.) into the cervical portion of the esophagus, towards the head. These rats were stomach fed through a cannula of PE-90 polyethylene tubing (Clay-Adams, Inc., New York) inserted through the cervical and thoracic portions of the esophagus into the stomach. The rats were anesthetized with ether while the cannulas were being inserted and the cannulations were completed 1-3 $\mathrm{h}$ before experiment.

Preparation of tissue homogenates. The animals were killed by decapitation. The tissues to be assayed were removed, chilled, and homogenized in cold glucose-free Tyrode's solution. The adult tissues were sometimes minced with scissors before being homogenized. The stomach wall and gastric contents were isolated as follows: The stomach was first clamped at the esophageal and duodenal apertures and then excised. The stomach was cut open and its contents removed and chilled. The stomach was then everted and its internal wall washed with cold $0.9 \% \mathrm{NaCl}$ solution to remove all traces of gastric contents.

Assay of lipolytic activity. The lipolytic activity in tissue homogenates, saliva, and gastric contents was measured by the amounts of diglyceride, monoglyceride, glycerol, and FFA produced by the hydrolysis of triglyceride in chylomicrons, milk, or corn oil.

Chylomicron triglyceride. Doubly labeled chylomicrons were isolated by centrifugation from thoracic duct chyle collected from fasted rats tube fed corn oil containing $\left[1-{ }^{14} \mathrm{C}\right]$ palmitic acid and trioleoyl- $\left[2-{ }^{8} \mathrm{H}\right]$ glycerol, and sus- 
pended in $4 \%$ albumin solution $(13,14)$. Hydrolysis of chylomicron triglyceride was measured in polypropylene assay tubes (Falcon Plastics, Div. of BioQuest, Oxnard, Calif.) containing $50 \mu \mathrm{l}$ of either $1 \mathrm{M}$ Tris-maleate $(\mathrm{pH}$ 5.0-6.0), $1 \mathrm{M}$ Tris- $\mathrm{HCl}(\mathrm{pH}$ 6.5-8.0), or $1 \mathrm{M}$ citrate$\mathrm{Na}_{2} \mathrm{HPO}_{4}$ buffer ( $\mathrm{pH} 3.2-7.4$ ), $200 \mu \mathrm{l}$ of $12.5 \%$ solution of bovine plasma albumin (Fraction V, Armour Pharmaceutical Co., Kanakee, I1l., lot E-29907), $2 \mu \mathrm{mol}$ of chylomicron triglyceride, $0.5-20 \mathrm{mg}$ of tissue homogenate, and water to a final volume of $0.5 \mathrm{ml}$. The assay mixture was incubated at $37^{\circ} \mathrm{C}$ in a Dubnoff shaking bath for $1-120 \mathrm{~min}$. At the end of the incubation the lipid in the mixture was extracted into hexane (15).

Triglyceride, diglyceride, monoglyceride, and FFA in the hexane extract were separated by thin-layer chromatography on silica gel sheets (16) (Eastman Chromagram sheet 6061, Eastman Kodak Co., Rochester, N. Y.) with a solvent system containing petroleum ether $\left(30-60^{\circ} \mathrm{C} \mathrm{bp}\right)$ : ethyl ether: glacial acetic acid $(120: 46.6: 1)$. The spots were stained with iodine vapor, cut out, and put into $15 \mathrm{ml}$ of scintillation fluid consisting of $4.2 \%$ Liquifluor (New England Nuclear, Pilot Chemicals Division, Boston, Mass., cat. no. NEF-903) in toluene for measurement of radioactivity. FFA in the hexane extract were sometimes isolated by the method of Borgström (17). The above scintillation fluid was also used for measuring radioactivity in FFA and total lipid extracts.

The amount of triglyceride hydrolyzed to glycerol was measured either by the decrease in ratio of ${ }^{8} \mathrm{H}$ to ${ }^{14} \mathrm{C}$ in the hexane extract of the assay mixture (14) or by the amount of $\left[{ }^{3} \mathrm{H}\right]$ glycerol produced. The latter was measured as follows: The isopropanol-aqueous lower phase of the extraction mixture was centrifuged at $500 \mathrm{~g}$ for $10 \mathrm{~min}$ to pack the precipitated protein. $2 \mathrm{ml}$ of the clear supernate were transferred to a polypropylene tube (Falcon) containing $1 \mathrm{~cm}^{3}$ Norit A (Fisher Scientific Co., Chemical Manufacturing Division, Pittsburg, $\mathrm{Pa}$.), vigorously shaken for $30 \mathrm{~s}$ on a Vortex shaker (Vortex-Genie, model $\mathrm{K}-550-\mathrm{G}$, Scientific Industries, Inc., Mineola, N. Y.) at a maximum speed, let stand for $30 \mathrm{~min}$ at room temperature with occasional shaking, and then centrifuged at $500 \mathrm{~g}$ for $15 \mathrm{~min}$. $0.5 \mathrm{ml}$ of the clear, colorless supernate were put in $15 \mathrm{~m}$ of scintillation fluid consisting of $24 \%$ Triton X-100 (New England Nuclear, Pilot Chemicals Division, Boston, Mass. cat. no. NEF-936) and 5\% Liquifluor in toluene. Water $(0.5 \mathrm{ml})$ was added to the counting vials to clear the mixture.

Radioactivity in lipid and glycerol samples was measured in a liquid scintillation spectrometer (Packard Tricarb model 314-EX, Packard Instrument Co., Inc., Downers Grove, Ill.). The gain and discriminators in the two channels of the spectrometer were set so that ${ }^{3} \mathrm{H}$ was counted with a relative efficiency of $100 \%$ in Channel a and totally discriminated from Channel $\mathrm{b}$, and ${ }^{14} \mathrm{C}$ was counted with a relative efficiency of $100 \%$ in Channel $\mathrm{b}$ and $28-30 \%$ in Channel a. Appropriate internal standards were used to determine corrections for quench.

Milk triglyceride. Rat milk was obtained as follows: lactating animals unsuckled for 1-2 $\mathrm{h}$ were anesthetized with ether, injected intramuscularly with $0.2 \mathrm{U}$ of pitocin (USP: Parke, Davis and Co., Detroit, Mich.), and milked with a device similar to that described by Feller and Boretos (18). Usually $2-4 \mathrm{ml}$ of milk was obtained from each rat.

Hydrolysis of rat milk triglyceride was measured in tubes containing $50 \mu \mathrm{l}$ of $1 \mathrm{M}$ citrate- $\mathrm{Na}_{2} \mathrm{HPO}_{4}$ buffer solution $\mathrm{pH} 5.4,200 \mu 1$ of $12.5 \%$ solution of bovine plasma albumin,
$50 \mu \mathrm{l}$ of milk containing $6 \mu \mathrm{mol}$ of triglyceride, $10 \mathrm{mg}$ of tissue homogenate, and water to a final volume of $0.5 \mathrm{ml}$. The mixture was incubated $15-60 \mathrm{~min}$ at $37^{\circ} \mathrm{C}$ in a Dubnoff shaking bath.

The products of hydrolysis of rat milk triglyceride were analyzed in the following way: The lipids were extracted into hexane and separated by thin-layer chromatography as described above. The glyceride and FFA spots were eluted with $5 \mathrm{ml}$ chloroform: methanol $(2: 1)$ and the chloroform phase was separated and washed according to the method of Folch, Lees, and Sloane Stanley (19). The glycerides were hydrolyzed to glycerol and FFA with tetraethyl-ammonium hydroxide (20), and glycerol was measured fluorometrically (20) and FFA, titrimetrically (15). Total fatty acid content of milk was calculated from the triglyceride content measured by the method of Rapport and Alonzo (21).

When adult rats were fed a mixture of bovine milk and cream (Half and Half, purchased from local food markets), the lipid in saliva and gastric contents was extracted into hexane (15). The hexane extract was then washed with "lower phase" according to the method of Dole and Meinertz (22) in order to remove short chain fatty acids and other acid contaminants. FFA were measured by titration and glycerides were separated by column chromatography (23-25) and measured as above.

Corn oil triglyceride. Hydrolysis of corn oil triglyceride was measured in assay tubes containing $50 \mu$ l of either $1 \mathrm{M}$ citrate- $\mathrm{Na}_{2} \mathrm{HPO}_{4}$ buffer $(\mathrm{pH} 5.4$ or 7.0 ) or $1 \mathrm{M}$ Tris- $\mathrm{HCl}$ buffer ( $\mathrm{pH} 8.1$ ), $300 \mu \mathrm{l}$ of $12.5 \%$ albumin solution, $5 \mu \mathrm{mol}$ of corn oil triglyceride, $5.0 \mathrm{mg}$ of tissue homogenate, and water to a final volume of $0.5 \mathrm{ml}$. The assay mixture was incubated at $37^{\circ} \mathrm{C}$ in a Dubnoff shaking bath for $30 \mathrm{~min}$. The products of hydrolysis were separated and measured as above.

\section{RESULTS}

Lipolytic activity in the stomach and oral secretory tissues of suckling and adult rats. Hydrolysis of chylomicron triglyceride by homogenates of stomach and oral tissues is shown in Table I. Homogenates of the stomach contents of suckling rats hydrolyzed chylomicron triglyceride, releasing $124 \mu \mathrm{eq}$ of FFA/g per h. This activity was not inhibited by the addition of $0.5 \mathrm{M} \mathrm{NaCl}$. The stomach wall, salivary glands, and anterior half of the tongue of suckling and adult rats had very little lipolytic activity even when tested over a $\mathrm{pH}$ range from 3.2 to 8.0 .

The posterior portion of the tongue, however, had a very potent lipolytic activity. Survey experiments localized the activity to the white tissue anterior to the circumvallate papilla (Fig. 1). The white tissue from tongue of suckling rats released from chylomicron triglyceride $2,700 \mu \mathrm{eq}$ of FFA/g per $\mathrm{h}$ and that of adult rats, $11,800 \mu \mathrm{eq} / \mathrm{g}$ per $\mathrm{h}$. Serial sections of adult rat tongue, examined grossly and microscopically, showed that the white tissue in the region of the circumvallate papilla consisted mostly of serous and mucous glands, and that the secretory ducts of the serous glands open into the furrows of the circumvallate papilla and the foli- 
TABLE I

Hydrolysis of Chylomicron Triglyceride by Homogenates of Stomach and Oral Tissues of Suckling and Adult Rats

\begin{tabular}{|c|c|c|c|c|}
\hline Tissue & $\begin{array}{l}\text { no. of } \\
\text { exps }\end{array}$ & FFA produced & $\begin{array}{l}\text { Optimal } \\
\text { pH }\end{array}$ & $\begin{array}{l}0.5 \mathrm{M} \\
\mathrm{NaCl}\end{array}$ \\
\hline & & $\mu e q / g$ per $h$ & & $\%$ \\
\hline \multicolumn{5}{|l|}{ Suckling rats } \\
\hline Stomach contents & 3 & $124 \pm 10$ & 5.4 & 0 \\
\hline Stomach wall & 2 & $\begin{array}{l}20 \pm 6 \\
31 \pm 13\end{array}$ & $\begin{array}{l}5.0 \\
8.0\end{array}$ & 0 \\
\hline $\begin{array}{l}\text { Submandibular and } \\
\text { sublingual glands } \\
\text { Anterior half }\end{array}$ & 2 & 0 & - & 一 \\
\hline of tongue & 2 & $12 \pm 2$ & 5.4 & - \\
\hline $\begin{array}{l}\text { White tissue near } \\
\text { circumvallate } \\
\text { papilla }\end{array}$ & 2 & $2,700 \pm 900$ & $4.5-5.4$ & 0 \\
\hline \multicolumn{5}{|l|}{ Adult rats } \\
\hline Submandibular gland & 1 & 6 & 7.4 & - \\
\hline Sublingual gland & 1 & 16 & 7.4 & - \\
\hline $\begin{array}{l}\text { Parotid gland } \\
\text { Anterior half }\end{array}$ & 1 & 4 & 7.4 & - \\
\hline of tongue & 2 & $19 \pm 1.0$ & 5.4 & 一 \\
\hline $\begin{array}{l}\text { White tissue near } \\
\text { circumvallate } \\
\text { papilla }\end{array}$ & 2 & $11,800 \pm 500$ & $4.9-5.4$ & $\mathbf{0}$ \\
\hline $\begin{array}{l}\text { White glandular } \\
\text { tissue anterior } \\
\text { to circumvallate } \\
\text { papilla }\end{array}$ & 4 & $50,100 \pm 10,000$ & $4.9-5.4$ & 0 \\
\hline Soft palate & 3 & $410 \pm 200$ & 5.4 & - \\
\hline $\begin{array}{l}\text { Anterior oral } \\
\text { pharyngeal } \\
\text { wall }\end{array}$ & 3 & $1,640 \pm 330$ & 5.4 & 一 \\
\hline $\begin{array}{l}\text { Lateral oral } \\
\text { pharyngeal } \\
\text { gland }\end{array}$ & 3 & $1,480 \pm 300$ & 5.4 & 一 \\
\hline
\end{tabular}

Values are means $\pm \mathrm{SE}$.

ate papillae (26) (Fig. 1). Homogenates of serous glands from adult tongues released from chylomicron triglyceride $50,000-90,000 \mu \mathrm{eq}$ of FFA/g per $\mathrm{h}$, whereas homogenates of mucous glands released only $800 \mu \mathrm{eq} / \mathrm{g}$ per $h$. The rate of hydrolysis of triglyceride by the serous glands was $40-70 \mathrm{mmol} / \mathrm{g}$ per $\mathrm{h}$.

Lipolytic activity, with an optimal $\mathrm{pH}$ of 5.4 , was also found in the soft palate, anterior oral pharyngeal wall (root of the tongue), and lateral oral pharyngeal glands (Fig. 1). The levels of activity (Table I), however, were less than $4 \%$ of that in the lingual serous glands, and about the same as that in the lingual mucous glands.

Nature of the lipolytic activity in tongue. The $\mathrm{pH}$ optimum for the lipolytic activity in tongue of suckling and adult rats was $4.5-5.4$ (Fig. 2). The activity was negligible at $\mathrm{pH}>7.4$. The low $\mathrm{pH}$ optimum and the lack of effect of $0.5 \mathrm{M} \mathrm{NaCl}$ (Table I) indicate that the lipolytic activity in tongue was not due to lipoprotein lipase $(27,28)$.

Homogenates of tongue of suckling rats hydrolyzed chylomicron triglyceride and rat milk triglyceride to diglyceride, monoglyceride, and FFA (Fig. 3). Diglyceride accounted for $85 \%$ of the glycerides formed during the first $5 \mathrm{~min}$ and $70 \%$ of that formed during the next $55 \mathrm{~min}$. Less than $6 \%$ of the triglyceride was hydro-
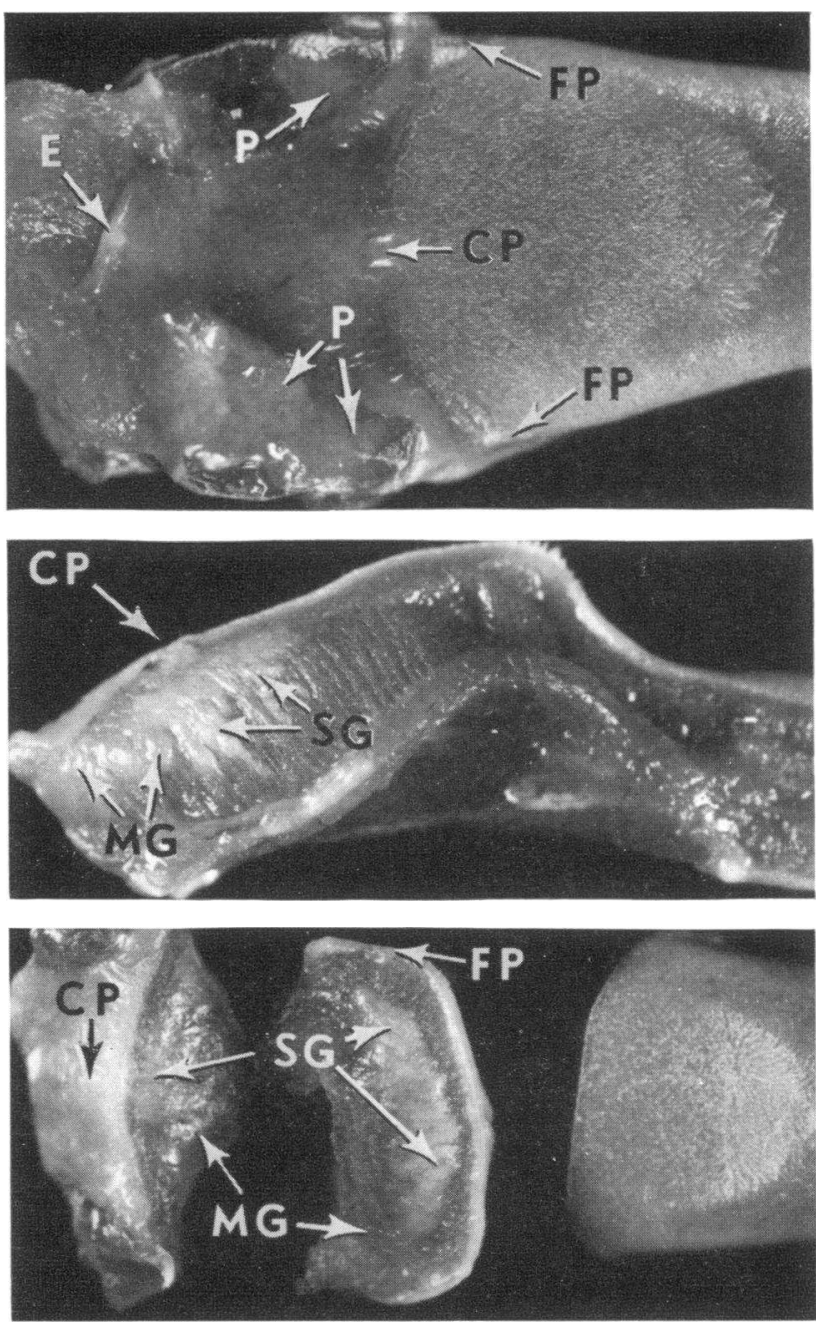

Figure 1 Rat tongue: (a) Top view showing circumvallate papilla (CP), foliate papillae (FP), lateral oral pharyngeal gland $(P)$, and epiglottis (E). (b) Sagittal section through the circumvallate papilla showing serous glands (SG) below and anterior to the papilla, and mucous glands (MG) posterior to the papilla. (c) Cross section through the foliate papillae and anterior to the circumvallate papilla, showing serous glands anterior and anterolateral to the circumvallate papilla and near the foliate papillae. Mucous glands are present below, lateral and posterior to the serous glands. 
lyzed to glycerol. Chylomicron triglyceride and milk triglyceride were hydrolyzed at similar rates during the first $15 \mathrm{~min}$ of incubation, about $1 \mathrm{mmol} / \mathrm{g}$ per $\mathrm{h}$.

Homogenates of lingual glandular tissue from adult rats also hydrolyzed chylomicron triglyceride to partial glycerides and FFA (Fig. 4). About 25\% was hydrolyzed to diglyceride and $5 \%$ to monoglyceride in the first $5 \mathrm{~min}$. Another $15 \%$ was hydrolyzed to diglyceride and an equal amount to monoglyceride during the next 55 min. Less than 5\% was hydrolyzed completely to glycerol.

Homogenates of lingual serous glands from adult rats hydrolyzed corn oil triglyceride, in 5\% albumin solution ( $\mathrm{pH}$ 5.4), to mostly diglyceride and FFA.

Nature of the lipolytic activity in gastric contcnts. The $\mathrm{pH}$ optimum for the hydrolysis of chylomicron triglyceride by homogenates of gastric contents of suckling rats was 5.4 (Fig. 2). Although the lipolytic activity in gastric contents was less than $5 \%$ of that in the tongue of suckling rats, it too formed mostly partial glycerides and FFA from chylomicrons, and diglyceride accounted for $85 \%$ of the glycerides formed (Fig. 5).

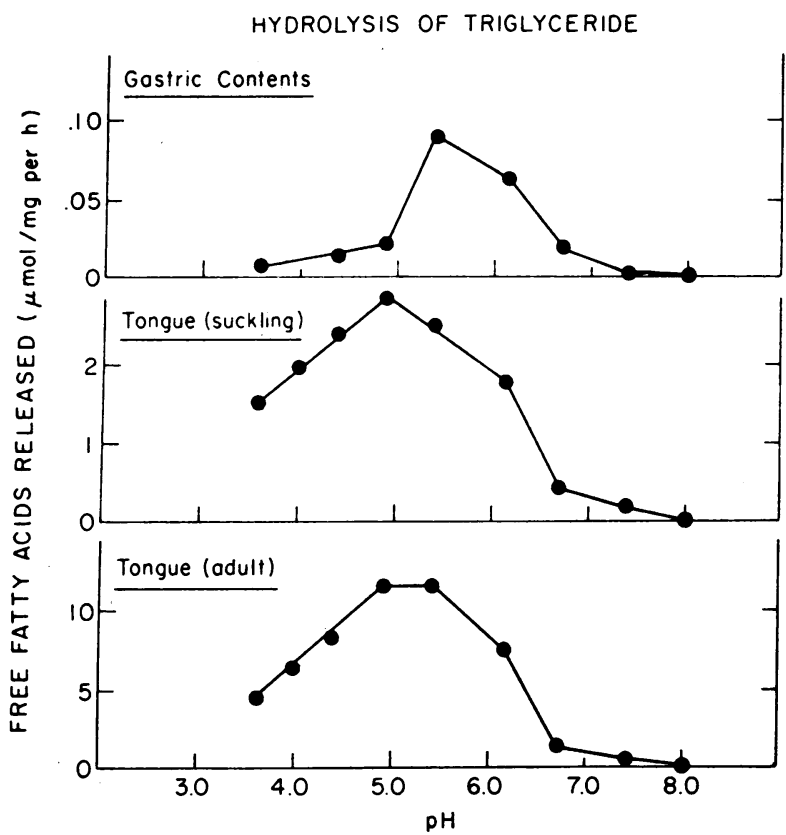

Figure 2 Effect of $\mathrm{pH}$ on hydrolysis of chylomicron triglyceride by homogenates of gastric contents (suckling) and tongue (suckling and adult). Each assay tube contained $2 \mu \mathrm{mol}$ of doubly labeled triglyceride, $0.5 \mathrm{ml}$ of $5 \%$ albumin in $0.1 \mathrm{M}$ citrate- $\mathrm{Na}_{2} \mathrm{HPO}_{4}$ buffer solution and either $20 \mathrm{mg}$ of stomach contents of suckling rats, $2.0 \mathrm{mg}$ of white tissue from near the circumvallate papilla of suckling rat tongue, or $0.5 \mathrm{mg}$ of white glandular tissue from near the circumvallate papilla of adult rat tongue. The values are means of three experiments.

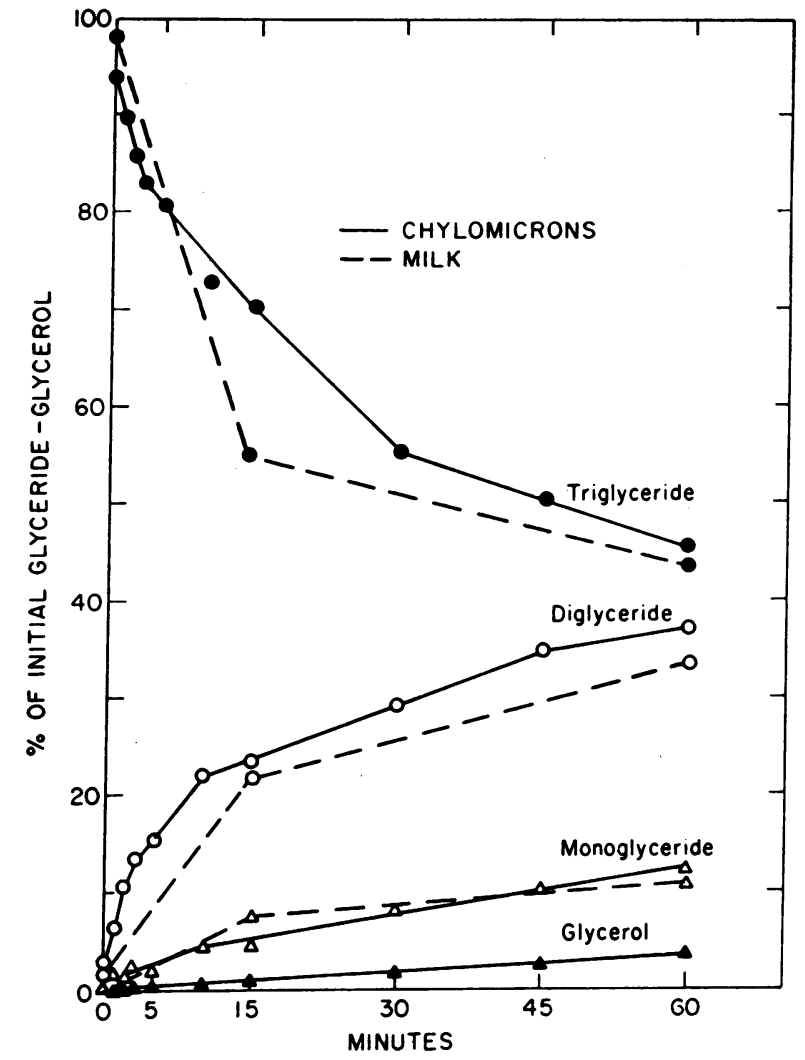

Figire 3 Suckling rat tongue: hydrclysis of chylomicron triglyceride and rat milk triglyceride by homogenates of white tissue from near the circumvallate papilla. Chylomicron triglyceride: Each tube contained $2 \mu \mathrm{mol}$ of doubly labeled triglyceride, $2 \mathrm{mg}$ of tissue homogenate, and 0.5 $\mathrm{ml}$ of $5 \%$ albumin in $0.1 \mathrm{M}$ citrate- $\mathrm{Na}_{2} \mathrm{HPO}_{4}$ buffer solution at $\mathrm{pH}$ 5.4. The mixture was. incubated at $37^{\circ} \mathrm{C}$. The values are means of three experiments. Milk triglyceride: Each tube contained $6 \mu \mathrm{mol}$ of triglyceride, $10 \mathrm{mg}$ of tissue homogenate, and $0.5 \mathrm{ml}$ of $5 \%$ albumin in $0.1 \mathrm{M}$ citrate$\mathrm{Na}_{2} \mathrm{HPO}_{4}$ buffer solution at $\mathrm{pH}$ 5.4. The mixture was incubated at $37^{\circ} \mathrm{C}$. The values are means of three experiments.

Milk triglyceride was quickly hydrolyzed in the stomach of adult rats fed ad lib. a mixture of bovine milk and cream; $12 \%$ was hydrolyzed within 10 min to diglyceride and FFA (Table II). Another $14 \%$ was hydrolyzed when the stomach contents were incubated with albumin solution for $1 \mathrm{~h}$ at $\mathrm{pH}$ 5.4. FFA accounted for $3.4 \%$ of the fatty acids in stomach contents 10 min after feeding and $9.1 \%$ after incubation for $1 \mathrm{~h}$. In another group of rats studied 30-40 min after feeding the milk-cream mixture, $8.5 \%$ of the fatty acids in the stomach were present as FFA, and incubation of the gastric contents increased the FFA content about $300 \%$ in $1 \mathrm{~h}$ (Table III). When saliva was diverted from the stomach, through a cannula inserted into the esophagus, only traces of 


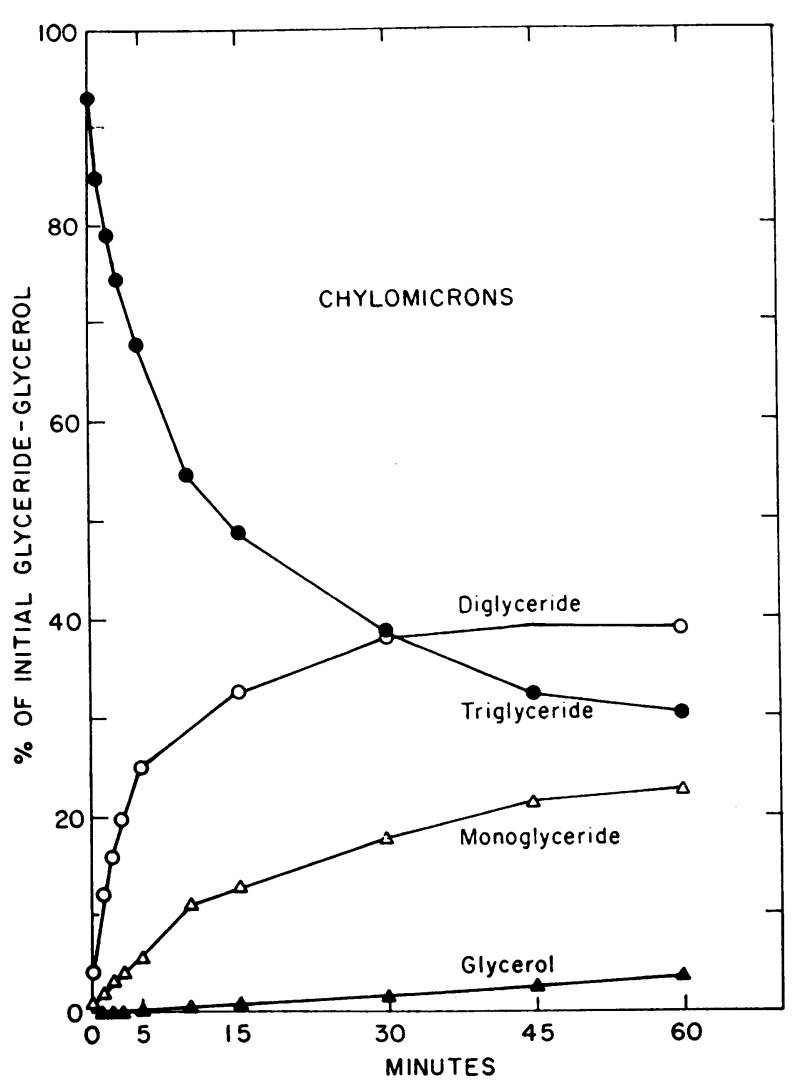

FIGURE 4 Adult rat tongue: hydrolysis of chylomicron triglyceride by homogenates of white glandular tissues near the circumvallate papilla. Assay: Same as in Fig. 2 except 0.5 of tissue was added to each tube. Values are means of three experiments.

FFA were found in the stomach after tube feeding the milk-cream mixture, and there was only a slight increase in FFA when the gastric contents were incubated for $1 \mathrm{~h}$ (Table III). Saliva collected from rats fed per os a few drops of the milk-cream mixture had lipolytic activity similar to that found in the tongue. The $\mathrm{pH}$ of the stomach contents was $4.5-5.5$ in both intact and cannulated rats fed the milk-cream mixture (Tables II and III).

Corn oil triglyceride fed in a purified diet was also quickly hydrolyzed in the stomach to diglyceride and FFA (Table IV). About $20 \%$ of the triglyceride was hydrolyzed within $10 \mathrm{~min}$ and $29 \%$ within $20 \mathrm{~min}$. The amount of triglyceride hydrolyzed was related to the amount of diet ingested. The $\mathrm{pH}$ of the gastric contents ranged from 4.3 to 5.0 in rats fed the corn oil diet (Table IV).

\section{DISCUSSION}

These studies show that the lingual serous glands in the rat contain a potent lipolytic activity which hydrolyzes long chain triglycerides of milk, corn oil, and chylomicrons to partial glycerides and FFA at $\mathrm{pH}$ 4.5-5.5. The anterior oral pharyngeal wall, the lateral oral pharyngeal glands, the soft palate, and the mucous glands of the tongue also contained lipolytic activity, but at a much lower level, less than $4 \%$ of that in the lingual serous glands. A similar activity was found in the saliva and gastric contents of rats fed milk. There was very little activity in the stomach, however, when saliva was excluded. The lipolytic activity was not present in gastric mucosa or in the large salivary glands. The $\mathrm{pH}$ of gastric contents was 4.5-5.5 in fed normal rats, both suckling and adult, and in tube-fed adult rats in which saliva was excluded from the stomach. The findings suggest that the lingual serous glands are the source of the lipolytic activity found in the stomach.

The lingual serous glands in adult female rats weighed about $60 \mathrm{mg}$, and the lipolytic activity in the glands ranged from 40 to $70 \mathrm{mmol}$ of triglyceride hydrolyzed/g per $h$. Therefore, the total activity present in the glands was sufficient to hydrolyze $2.4-4.2 \mathrm{mmol}$ of triglyceride

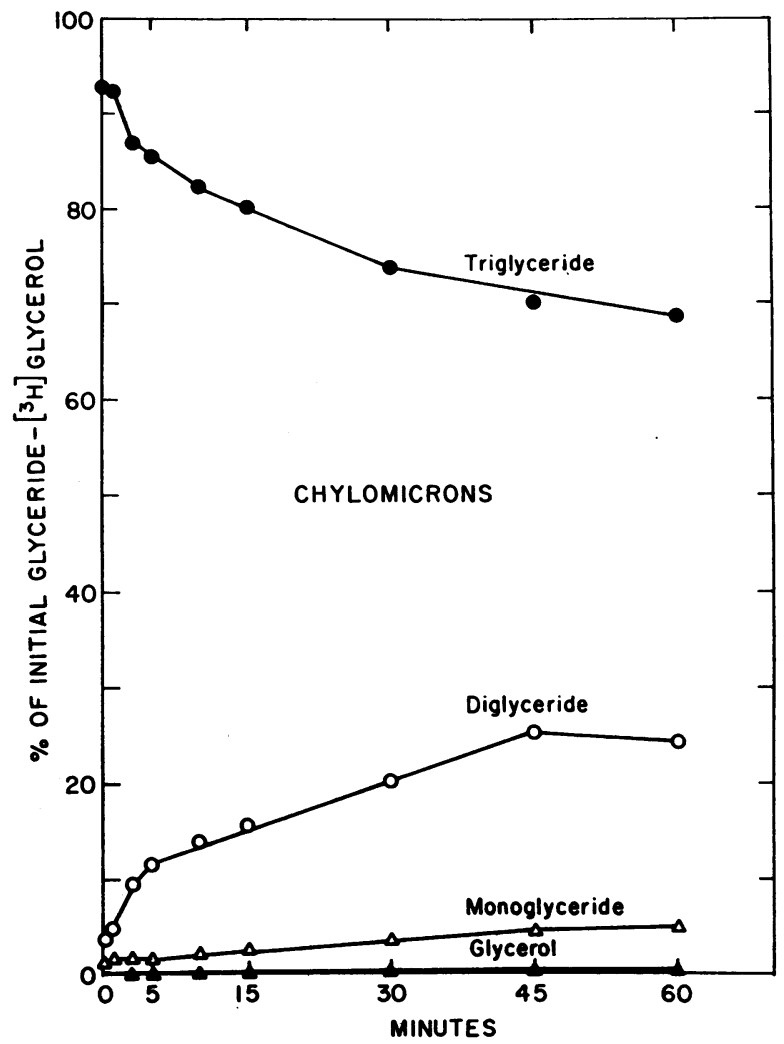

FIGURE 5 Gastric contents of suckling rats: hydrolysis of chylomicron triglyceride. Assay: Same as in Fig. 2 except $20 \mathrm{mg}$ of homogenized gastric contents were added to each tube. Values are means of three experiments. 
TABLE II

Hydrolysis of Bovine Milk Triglyceride in the Stomach of Adult Rats

\begin{tabular}{|c|c|c|c|c|c|c|c|c|c|}
\hline \multirow{3}{*}{ Specimen } & \multirow{3}{*}{$\begin{array}{c}\text { no. of } \\
\text { exps }\end{array}$} & \multirow{3}{*}{$\mathrm{pH}$} & \multicolumn{6}{|c|}{ Lipid composition } & \multirow{2}{*}{$\begin{array}{c}\text { Amount } \\
\text { of tri- } \\
\text { glyceride } \\
\text { hydrolyzed }\end{array}$} \\
\hline & & & \multicolumn{2}{|c|}{ Total fatty acids } & Triglyceride & Diglyceride & Monoglyceride & FFA & \\
\hline & & & $\mu e q$ & $\mu e q / g$ wet wt & \multicolumn{3}{|c|}{$\%$ of glyceride-glycerol } & $\begin{array}{l}\% \text { of total } \\
\text { fatty acids }\end{array}$ & $\mu \mathrm{mol}$ \\
\hline Test meal & 1 & 7.0 & - & 495 & 94.8 & 4.9 & 0.2 & 0.5 & - \\
\hline $\begin{array}{l}\text { Gastric content } \\
\text { after feeding }\end{array}$ & & & & & & & & & \\
\hline $\begin{array}{l}10 \text { min } \\
\text { Incubated }\end{array}$ & 4 & $4.5-5.5$ & $1,330 \pm 310$ & $543 \pm 45$ & $83.3 \pm 1.7$ & $16.4 \pm 1.4$ & $0.4 \pm 0.1$ & $3.4 \pm 0.2$ & 51 \\
\hline $\begin{array}{l}15 \text { min } \\
\text { Incubated }\end{array}$ & 2 & 5.4 & - & - & $76.8 \pm 2.8$ & $22.5 \pm 2.5$ & $0.7 \pm 0.1$ & $6.1 \pm 1.0$ & 80 \\
\hline $60 \mathrm{~min}$ & 2 & 5.4 & - & - & $70.0 \pm 2.0$ & $29.0 \pm 2.0$ & $0.9 \pm 0.1$ & $9.1 \pm 0.8$ & 110 \\
\hline
\end{tabular}

Rats were fed for 2 days a mixture of bovine milk and cream. They were then fasted overnight and fed the milk-cream mixture ad lib. for $10 \mathrm{~min}$. The gastric contents were then removed and samples were taken for analysis and incubation with $7.5 \%$ albumin solution at $\mathrm{pH} 5.4$ and $38^{\circ} \mathrm{C}$. Values are means $\pm \mathrm{SE}$.

in $1 \mathrm{~h}$. When adult female rats are fed the commercial stock diet used in this study, Purina laboratory chow (fatty acid content, $4.5 \%$ ), they eat about $15 \mathrm{~g}$ of diet containing $0.8 \mathrm{mmol}$ of triglyceride per day (29). Thus, the lipolytic activity in the lingual serous glands is $3-5$ times that needed to hydrolyze in $1 \mathrm{~h}$ the triglyceride ingested each day.

The lingual serous glands (of Ebner) secrete through ducts which empty into the furrows of the circumvallate and foliate papillae of the tongue $(26,30,31)$. It has been proposed that their secretion "serves to wash out the taste buds" (31). Our study in rats, however, suggests that these glands secrete a lipase that acts in the stomach. Studies in calves have also demonstrated a lipolytic activity in saliva, called "pregastric esterase," which hydrolyzes triglyceride to FFA in the stomach (abomasum) $(11,32,33)$. The lipolytic activity was also found in glandular tissue from the circumvallate region of the tongue, the glossoepiglottic area of the pharynx, and the pharyngeal end of the esophagus, suggesting that these tissues were the source of the lipolytic activity present in saliva $(12,34)$. Additional studies are needed to determine the cellular origin of the lipolytic activity in the saliva of calves since most of the glands in the base of the tongue and in the esophagus are of the mucous type (12).

Evidence of intragastric hydrolysis of triglyceride has also been seen in other species. One-third of the lipid in the stomach was FFA $4 \mathrm{~h}$ after a fat meal in normal dogs and dogs deprived of pancreatic lipase (35). FFA also accounted for $10-20 \%$ of the fatty acids in the stomach of humans $20 \mathrm{~min}$ after a test meal containing corn oil (36). In addition, diglyceride and FFA were formed when long chain triglycerides were incubated with gastric juice obtained free of duodenal contents from fasting human subjects (37).

It is generally thought that dietary triglycerides are not appreciably affected by enzymes until they reach the duodenum, and that the lipid is emulsified in the stomach by the "churning, kneading, and squirting movements" of the stomach wall (38-40). The above studies, however, show that triglyceride is readily hydrolyzed in the stomach

TABLE III

Effect of Exclusion of Saliva on the Hydrolysis of Borine Milk Triglyceride in the Stomach of Adult Rats*

\begin{tabular}{|c|c|c|c|c|}
\hline \multirow[b]{2}{*}{ Group } & \multirow[b]{2}{*}{$\begin{array}{l}\text { no. of } \\
\text { exps }\end{array}$} & \multirow{2}{*}{$\begin{array}{c}\mathrm{pH} \text { of } \\
\text { gastric } \\
\text { contents }\end{array}$} & \multicolumn{2}{|c|}{$\begin{array}{c}\text { FFA formed in gastric } \\
\text { contents } \neq\end{array}$} \\
\hline & & & $\begin{array}{l}\text { In vivo\$ } \\
(35 \mathrm{~min})\end{array}$ & $\begin{array}{l}\text { In vitroll } \\
(60 \mathrm{~min})\end{array}$ \\
\hline & & & \multicolumn{2}{|c|}{$\%$ of total fatty acids } \\
\hline Control & 5 & $4.5-5.5$ & $8.5 \pm 0.9$ & $32.6 \pm 3.4$ \\
\hline Cannulated & 4 & $4.5-5.5$ & $0.8 \pm 0.02$ & $3.3 \pm 1.1$ \\
\hline
\end{tabular}

* Flow of saliva to the stomach was diverted by inserting a cannula into the cervical portion of the esophagus 1-3 h before experiment. The cannulated rats were tube fed and the control rats were fed ad lib. $6 \mathrm{ml}$ of a mixture of bovine milk and cream containing $10-12 \%$ triglyceride by weight. All rats were fasted overnight before experiment. Values are means \pm SE. $\ddagger$ FFA comprised $0.3 \%$ of the fatty acids in the milk-cream mixture.

§In vivo, the gastric contents were analyzed $30-40 \mathrm{~min}$ after feeding.

\|I In vitro, a sample of the stomach contents was incubated in $7.5 \%$ albumin solution at $\mathrm{pH} 5.4$ for $60 \mathrm{~min}$. 
TABLE IV

Hydrolysis of Corn Oil Triglyceride in the Stomach of Adult Rats

\begin{tabular}{|c|c|c|c|c|c|c|c|c|c|}
\hline \multirow{3}{*}{ Specimen } & \multirow{3}{*}{$\begin{array}{c}\begin{array}{c}\text { Duration } \\
\text { of } \\
\text { feeding }\end{array} \\
\text { min }\end{array}$} & \multirow{3}{*}{$\mathrm{pH}$} & \multicolumn{6}{|c|}{ Lipid composition } & \multirow{2}{*}{$\begin{array}{c}\text { Amount } \\
\text { of tri- } \\
\text { glyceride } \\
\text { hydrolyzed }\end{array}$} \\
\hline & & & \multicolumn{2}{|c|}{ Total fatty acids } & $\begin{array}{l}\text { Triglyc- } \\
\text { eride }\end{array}$ & $\begin{array}{l}\text { Diglyc- } \\
\text { eride }\end{array}$ & $\begin{array}{l}\text { Monoglyc- } \\
\text { eride }\end{array}$ & FFA & \\
\hline & & & $\mu e q$ & $\begin{array}{l}\mu e q / g \\
d r y w l^{*}\end{array}$ & \multicolumn{3}{|c|}{$\%$ of glyceride-glycerol } & $\begin{array}{l}\% \text { of total } \\
\text { fatty acids }\end{array}$ & $\mu m o l$ \\
\hline Test meal & - & 7.0 & - & 285 & 90.3 & 8.2 & 1.6 & 0.6 & - \\
\hline \multicolumn{10}{|c|}{ Gastric contents } \\
\hline Rat no. 1 & 10 & 4.7 & 410 & 316 & 72.6 & 23.7 & 3.8 & 16.3 & 24 \\
\hline Rat no. 2 & 10 & 4.3 & 563 & 268 & 69.0 & 27.0 & 4.4 & 17.2 & 40 \\
\hline Rat no. 3 & 20 & 4.5 & 557 & 396 & 67.1 & 29.5 & 3.4 & 20.2 & 43 \\
\hline Rat no. 4 & 20 & 5.0 & 1,700 & 315 & 56.4 & 35.6 & 8.0 & 25.8 & 192 \\
\hline
\end{tabular}

Rats were fed for 2 days a purified diet containing $8 \%$ corn oil, $22 \%$ vitamin-free casein, $63 \%$ corn starch, and adequate amounts of vitamins and minerals. They were then fasted overnight and fed the diet ad lib. for 10 or 20 min. Gastric contents were then removed for analysis.

* The dry weight of the test meal was equal to $91 \%$ of the wet weight, and the dry weight of the gastric contents ranged from 44 to $60 \%$ of the wet weight.

(Tables II and IV). We propose that partial hydrolysis in the stomach is the first step in the digestion of triglyceride, and that this reaction is catalyzed by lingual lipase.

\section{ACKNOWLEDGMENTS}

The authors are grateful to Mr. Barker Dixon, Mrs. Theresa R. Clary, Mrs. Edna V. Hill, and Miss Alice W. True for their expert assistance in these studies.

\section{REFERENCES}

1. Hamosh, M., and R. O. Scow. 1970. Plasma triglyceride and lipoprotein lipase activity in pregnant and lactating rats. Excerpta Medica Foundation, Amsterdam. International Congress Series no. 213. Nutrition, 207.

2. Helander, H. F., and T. Olivecrona. 1970. Lipolysis and lipid absorption in the stomach of the suckling rat. Gastroenterology. 59: 22.

3. Bennett Clark, S., B. Brause, and P. R. Holt. 1969. Lipolysis and absorption of fat in the rat stomach. Gastroenterology. 56: 214.

4. Barrowman, J. A., and S. J. Darnton. 1970. The lipase of rat gastric mucosa. Gastroenterology. 59: 13.

5. Korn, E. D. 1962. The lipoprotein lipase of cow's milk. J. Lipid Res. $3: 246$.

6. McBride, O. W., and E. D. Korn. 1963. The lipoprotein lipase of mammary gland and the correlation of its activity to lactation. J. Lipid Res. 4: 17.

7. Robinson, D. S. 1963. Changes in the lipolytic activity of the guinea pig mammary gland at parturition. $J$. Lipid Res. 4: 21.

8. Chandan, R. C., and K. M. Shahani. 1964. Milk lipases. A review. J. Dairy Sci. $47: 471$.

9. Hamosh, M., and R. O. Scow. 1971. Lipoprotein lipase activity in guinea pig and rat milk. Biochim. Biophys. Acta. 231: 283.

10. Cohen, M., M. B. Reginald, G. H. Morgan, and A. F. Hofmann. 1971. Lipolytic activity of human gastric and duodenal juice against medium and long chain triglycerides. Gastroenterology. 60: 1 .

11. Otterby, D. E., H. A. Ramsey, and G. H. Wise. 1964. Source of lipolytic enzymes in the abomasum of the calf. J. Dairy Sci. 47 : 997.

12. Ramsey, H. A., G. H. Wise, and S. B. Tove. 1956. Esterolytic activity of certain alimentary and related tissues from cattle in different age groups. J. Dairy Sci. 39: 1312.

13. Scow, R. O., Y. Stein, and O. Stein. 1967. Incorporation of dietary lecithin and lysolecithin into lymph chylomicrons in the rat. J. Biol. Chem. 242: 4919.

14. Hamosh, M., T. R. Clary, S. S. Chernick, and R. O. Scow. 1970. Lipoprotein lipase activity of adipose and mammary tissue and plasma triglyceride in pregnant and lactating rats. Biochim. Biophys. Acta. 210: 473.

15. Chernick, S. S., and M. Novak. 1970. Effect of insulin on FFA mobilization and ketosis in fasting pregnant rats. Diabetes. 19: 563.

16. Stein, O., R. O. Scow, and Y. Stein. 1970. FFA- ${ }^{3} \mathrm{H}$ uptake by perfused adipose tissue: electron microscopic autoradiographic study. Am. J. Physiol. 219: 510 .

17. Borgström, B. 1952. Investigation on lipid separation methods. Separation of cholesterol esters, glycerides, and free fatty acids. Acta Physiol. Scand. 25: 111.

18. Feller, W. F., and I. Boretos. 1967. Semiautomatic apparatus for milking mice. J. Natl. Cancer Inst. 38: 11.

19. Folch, J., M. Lees, and G. H. Sloane Stanley. 1957. A simple method for the isolation and purification of total lipids from animal tissues. J. Biol. Chem. 226: 497.

20. Chernick, S. S. 1969. Determination of glycerol in acyl glycerols. Methods in Enzymol. 14: 627.

21. Rapport, M. M., and M. Alonzo. 1959. Photometric determination of fatty acid ester groups in phospholipides. J. Biol. Chem. 217: 193.

22. Dole, V. P., and H. Meinertz. 1960. Microdetermination of long chain fatty acids in plasma and tissues. J. Biol. Chem. 235: 2595.

23. Borgström, B. 1954. Investigation on lipid separation methods III. Separation of tri-, di-, 1-mono, and 2mono-glycerides. Acta Physiol. Scand. 30: 1954. 
24. Creech, B. G. 1961. Isolation of neutral lipids by column chromatography. J. Am. Oil Chem. Soc. 38: 540.

25. Fillerup, D. L., and J. F. Meads. 1953. Chromatographic separation of the plasma lipids. Proc. Soc. Exp. Biol. Med. 83: 574 .

26. Fish, H. S., P. D. Malorie, and C. P. Richter. 1944. The anatomy of the tongue of the domestic norway rat. Anat. Rec. 89: 429.

27. Robinson, D. S. 1963. The clearing factor lipase and its action in the transport of fatty acids between the blood and the tissues. In Advances in Lipid Research. R. Paoletti, and D. Kritchevsky, editors. Academic Press, Inc., New York. 1: 133.

28. Robinson, D. S. 1970. The function of the plasma triglycerides in fatty acid transport. Compr. Biochem. 18: 51 .

29. Scow, R. O., S. S. Chernick, and M. S. Brinley. 1964 Hyperlipemia and ketosis in the pregnant rat. Am. J. Physiol. 206: 796

30. Sognnaes, R. F., and M. L. Moss. 1966. Oral cavity. In Histology, R. O. Greep, editor. McGraw-Hill Book Co., New York. 2nd edition. 463.

31. Bloom, W., and D. W. Fawcett. 1962. Histology. W. B. Saunders Co., Philadelphia, Pa. 8th edition. 405

32. Ramsey, H. A., and J. W. Young. 1961. Role of pre- gastric esterase in the abomasal hydrolysis of milk fat in the young calf. J. Dairy Sci. 44: 2227.

33. Otterby, D. E. H. A. Ramsey, and G. H. Wise. 1964. Lipolysis of milk fat by pregastric esterase in the abomasum of the calf. J. Dairy Sci. 47: 993.

34. Ramsey, H. A., and J. W. Young. 1961. Substrate specificity of pregastric esterase from the calf. J. Dairy Sci. $44: 2304$

35. Douglas, G. J., Jr., A. J. Reinauer, W. C. Brooks, and and J. H. Pratt. 1953. The effect on digestion and absorption of excluding the pancreatic juices from the intestine. Gastroenterology. 23: 452.

36. Borgström, B., A. Dahlquist, G. Lundh, and J. Sjovall. 1957. Studies of intestinal digestion and absorption in the human. J. Clin. Invest. 36: 1536.

37. Bank, S., L. H. Krut, I. N. Marks, B. Bronle-Stewart, and P. J. Le R. Uys. 1964. Hydrolysis of fat by human gastric juice. Gut. 5: 480.

38. Senior, J. R. 1964. Intestinal absorption of fats. $J$. Lipid Res. 5 : 495.

39. Hofmann, A. F. 1966. A physicochemical approach to the intraluminal phase of fat absorption. Gastroenterology. 50: 56.

40. Johnston. J. M. 1970. Intestinal absorption of fats. Compr. Biochem. 18: 1 . 